\title{
MOLECULAR IDENTIFICATION OF PROTEOLITIC BACTERIA FROM MANGROVE SEDIMENT IN DUMAI MARINE STATION
}

\author{
Abdi Hikmat Petra Zebua*1, Nursyirwani ${ }^{2}$, Feliatra ${ }^{2}$ \\ ${ }^{1}$ Student of The Faculty of Fisheries and Marine Universitas Riau, Pekanbaru \\ ${ }^{2}$ Lecturer at The Faculty of Fisheries and Marine Universitas Riau, Pekanbaru \\ *abdizebua1997@gmail.com
}

\begin{abstract}
Proteolytic bacteria have important role in the degradation of complex compounds to simple compound by the enzyme proteases. Sediment in mangrove ecosystem of Dumai Marine Station may contain the bacteria. This research aims to identify the proteolytic bacteria of mangrove sediments molecularly and to examine the antagonism of pathogenic bacteria. The method used in this research was survey. The results obtained 10 bacterial isolates (AZ1, AZ2, AZ3, AZ4, AZ6, AZ10, AZ11, AZ15, AZ18, and AZ20). Identification using 16S rRNA analysis revealed that 3 isolates showed different results, namely AZ2 had a similarity to Bacillus proteolyticus with strain MCCC 1A00365, AZ6 had a similarity to the bacteria $B$. monlinensis with strain BL4-6 and AZ20 had similarity to the bacterium $B$. toyonensis with strain MCCC 1A00365 BCT-7112. Three of the 10 isolates that had the highest inhibition against pathogens. Isolates AZ2 shovued inhibition zone against Pseudomonas aeruginosa with a diameter of $9.65 \mathrm{~mm}$, AZ6 shovued inhibition zone against Escherichia coli bacteria with a diameter of $5.18 \mathrm{~mm}$, and AZ20 shovued inhibition zone against Vibrio alginolyticus bacteria with a diameter of 4, $01 \mathrm{~mm}$.
\end{abstract}

Keywords: Proteolytic Bacteria, Antagonism, $16 S$ rRNA Sequence, Pathogenic Bacteria

\section{PENDAHULUAN}

Stasiun Kelautan Purnama Dumai sebagai lokasi penelitian berada pada pesisir timur Pulau Sumatera dengan substrat dasar berlumpur yang banyak ditumbuhi mangrove dengan berbagai jenis biota yang hidup didalamnya. Kondisi hutan mangrove yang berada di kawasan Stasiun Kelautan Purnama Dumai.

Bakteri memainkan peran penting dalam ekosistem mangrove terutama dalam mengurai serasah daun. Keberadaan bakteri ini sangat dipengaruhi oleh berbagai faktor lingkungan (Yahya et al., 2014). Beberapa bakteri proteolitik yang menghasil enzim protease digunakan dalam skala industri terutama digunakan dalam industri detergen, farmasi, produk-produk kulit, pengempukan daging, hidrolisat protein, produk-produk makanan, maupun pengolahan limbah industri. Penggunaan mikroorganisme sebagai penghasil enzim juga merupakan salah satu upaya yang lebih mudah dan efisien karena pertumbuhannya yang cepat, dapat tumbuh pada substrat yang mudah didapat (Yusriah dan Kuswytasari, 2013).

Bakteri proteolitik di uji antagonisme terhadap pertumbuhan bakteri patogen. Bakteri patogen merupakan bakteri yang menyebabkan penyakit pada ikan. Aktivitas mikroba pada bakteri sedimen laut dari Perairan Pulau Lemukutun, diperoleh sebanyak 4 isolat. Penapisan aktivitas antibakteri dilakukan dengan metode cross streak. Bakteri patogen yang digunakan 
adalah adalah Pseudomonas aeruginosa, Escherichia coli, Vibro alginolyticus dan Salmonella typhimurium. Aktivitas antibakteri terbaik diperoleh pada bakteri SKA04 dapat menghambat bakteri patogen S. typhimurium. Penapisan aktivitas enzim ekstraseluler dilakukan untuk mengetahui potensi isolat bakteri sedimen laut dalam menghasilkan enzim amilolitik dan lipase (Idiawati et al., 2019).

Untuk menentukan jenis bakteri proteolitik dari sedimen ekosistem mangrove perlu dilakukan identifikasi secara molekuler. Metode terbaik untuk menentukan taksonomi suatu mikroorganisme adalah metode yang menggunakan hubungan kekerabatan DNA (genotip) dan karakterisasi fenotip dalam mengklasifikasi mikroorganisme. Untuk melakukan analisis komposisi gen dan keanekaragaman filogenetika suatu mikroorganisme metode yang paling sering digunakan adalah menggunakan analisis skuensing gen 16S rRNA. Teknik ini dilakukan dengan menganalisis struktur atau susunan basa nukleotida DNA yang terdapat di daerah $16 \mathrm{~S}$ rRNA.

Tujuan penelitian ini dilakukan adalah sebagai untuk mengisolasi dan mengidentifikasi jenis bakteri proteolitik pada sedimen di ekosistem mangrove di Stasiun Kelautan Kelurahan Purnama Kota Dumai secara molekuler dan menguji antagonisme untuk bakteri proteolitik terhadap bakteri patogen

\section{METODE PENELITIAN}

Penelitian ini dilaksanakan pada bulan April - Mei 2019. Identifikasi bakteri proteolitik dilakukan di Laboratorium Mikrobiologi Laut Jurusan Ilmu Kelautan Fakultas Perikanan dan Kelautan, dan di Laboratorium Genetika Jurusan Biologi Fakultas Matematika dan Ilmu Pengetahuan Alam Universitas Riau Pekanbaru.

Metode yang digunakan pada penelitian ini adalah metode survei yaitu dengan mengambil sampel sedimen di lapangan dan mengisolasi dan identifikasi bakteri proteolitik di laboratorium.

\section{Penentuan Lokasi Penelitian}

Lokasi pengambilan sampel pada 3 titik stasiun, setiap titik stasiun dilakukan pengulangan pengambilan sampel sebanyak 3 kali. Pada stasiun 1 yaitu pada hutan mangrove, kemudian pada stasiun 2 yaitu rumah kapal, dan stasiun 3 pada muara sungai mesjid. Setiap titik sampling berjarak 50 meter dan setiap pengulangan berjarak 10 meter.

Pengambilan sampel sedimen diambil dari ekosistem mangrove Kelurahan Purnama Kota Dumai dengan menggunakan spatula, kemudian sampel yang diperoleh dimasukkan ke dalam kantong plastik dan diberi label. Sampel sedimen yang sudah ada dimasukkan kedalam ice box dan dilapisi es, kemudian sampel dibawa ke Laboratorium Mikrobiologi Laut untuk dianalisis.

\section{Sterilisasi Alat dan Pembuatan Media}

Peralatan yang digunakan seperti tabung reaksi, tabung erlenmeyer dibungkus dengan aluminium foil, cawan petri dibungkus dengan kertas padi lalu dimasukkan kedalam keranjang yang telah disiapkan, keranjang dimasukkan kedalam autoklaf untuk sterilisasi dengan suhu $121^{\circ} \mathrm{C}$ dengan tekanan $2 \mathrm{~atm}$ dalam waktu 15 menit. Setelah proses autoklaf selesai, alat-alat tersebut dibiarkan kering kemudian disusun pada lemari penyimpanan.

Pembuatan media Zobell 2216 E adalah sebagai berikut : 5 gram Bacto Pepton, 1 gram Yeast extrat, dan 15 gram Bacto agar, dimasukkan dalam Erlenmeyer dan dilarutkan dalam 1 liter air laut steril. Lalu sebagian media dituang ke dalam tabung reaksi (media agar tegak dan miring). Kemudian media disterilkan dalam autoklaf dengan suhu $121{ }^{\circ} \mathrm{C}$ selama 15 menit. Setelah itu sisa media dituang ke dalam cawan petri. Setelah mengeras 
semua media disimpan dengan posisi terbalik selama 24 jam pada suhu $36^{\circ} \mathrm{C}$

\section{Isolasi dan Seleksi Bakteri}

Sampel sedimen ditimbang sebanyak 1 gram, lalu dimasukkan ke dalam larutan fisiologis $(\mathrm{NaCl} 0,9 \%)$ yang terdiri dari $1000 \mathrm{ml}$ akuades. Sebanyak 10 gram dari masing-masing sampel diambil, kemudian dimasukkan ke dalam labu erlenmeyer yang berisi $90 \mathrm{ml}$ air laut steril, vortex hingga homogen dan diperoleh pengenceran $10^{-1}$. Selanjutnya dari pengenceran $10^{-1}$ diambil $1 \mathrm{ml}$ menggunakan pipet steril kemudian dimasukkan ke dalam $9 \mathrm{ml}$ air laut steril dan diperoleh pengenceran $10^{-2}$. Demikian selanjutnya dilakukan pengenceran hingga diperoleh pengenceran $10^{-5}, 10^{-6}$ dan $10^{-7}$. Pada masing-masing pengenceran diambil $1 \mathrm{ml}$ suspensi bakteri menggunakan pipet steril dan dimasukkan ke dalam masingmasing cawan petri steril. Selanjutnya di tambahkan ke dalamnya $10 \mathrm{ml}$ media Zobell $2216 \mathrm{E}$ (dengan suhu sekitar $45^{\circ} \mathrm{C}$ yang telah dicairkan sebelumnya) dan diratakan. Selanjutnya cawan petri tersebut dibungkus dengan kertas pembungkus dan diinkubasikan selama 2 × 24 jam.

Skrining dilakukan berdasarkan kemampuan mendegradasi protein dengan pendekatan aktivitas enzim protase. Uji aktivitas produksi enzim protease ekstraseluler dilakukan dengan prosedur menurut Biairagi et al. (2002). Kultur cair solat-isolat yang diperoleh dari hasil isolasi diinokulasikan ke paper disc blank yang telah diletakan pada media media Zobell 2216 E yang diperkaya dengan skim milk (1\%). Inkubasi pada $32^{\circ} \mathrm{C}$ selama 48 jam.

\section{Pemisahan dan Pemurnian Isolat Bakteri}

Pemisahan dan pemurnian isolat bakteri dilakukan dengan metoda goresan (streak method). Masing-masing cawan petri pada tiap pengenceran diambil kolonikoloni bakteri yang menampakkan morfologi dan warna yang berbeda Selanjutnya masing-masing koloni bakteri tersebut digoreskan pada permukaan media Zobell 2216 E pada masing-masing cawan petri yang telah disiapkan. Selanjutnya cawan-cawan petri tersebut diinkubasikan pada suhu kamar selama 2 x 24 jam dan diamati pertumbuhannya, apakah sudah terpisah dan menjadi kultur murni atau belum. Apabila masih terdapat campuran bakteri pada cawan petri tersebut, maka dilakukan pemisahan kembali dengan metode goresan hingga diperoleh kultur murni pada masing-masing cawan petri. Kultur murni dari isolat bakteri tersebut dipindahkan ke dalam media agar miring Zobell 2216 E pada tabung reaksi dengan teknik goresan.

\section{Identifikasi Isolat}

Identifikasi isolat bakteri proteolitik dilakukan secara fenotip dan genotip. Secara fenotip dilakukan melalui pengamatan morfologi dan sel dan uji-uji biokimia Sedangkan secara genotip dilakukan dengan pengamatan secara melekuler dengan teknik 16S rRNA.

Pengamatan morfologi koloni meliputi jumlah, bentuk, ukuran, tepian, permukaan dan warna koloni dapat diamati secara langsung pada isolat yang tumbuh pada media. Pengamatan bentuk sel dilakukan dengan langsung yaitu melihat secara morfologi dari tiap koloni yang tumbuh.

Identifikasi bakteri berdasarkan uji aktivitas biokimia dilakukan dengan cara membandingkan aktivitas biokimia setiap bakteri. Aktivitas biokimia setiap jenis bakteri berbeda. Hal ini disebabkan karena setiap bakteri mempunyai aktivitas enzimatik yang berbeda.

\section{Isolasi DNA}

Amplifikasi DNA dilakukan dengan menggunakan polymerase chain reaction (PCR) $50 \mu \mathrm{l}$ dilakukan dengan menggunakan Primer 27F: 5' 
AGAGTTTGATCMTGGCTCAG 3' dan 1492R: 5' ACCTTGTTACGACTT 3' dengan cara template DNA diambil sebanyak $1 \mu$ dipindahkan ke dalam tabung berukuran $0,2 \mathrm{ml}$ dan dimasukkan $49 \mu \mathrm{l}$ master mix.Tabung dimasukkan ke dalam thermal cycler. Proses pra-PCR dijalankan pada suhu $94{ }^{\circ} \mathrm{C}$ selama 3 menit.

\section{Purifikasi dan Sekuensing}

Sampel DNA dikirim ke PT. Genetika Science Indonesia Jakarta Barat untuk dipurifikasi dan disekuensing di First Base. Data hasil sekuensing dianalisis lebih lanjut. Purifikasi DNA hasil PCR dari gel agarose dilakukan dengan menggunakan Geneaid® Gel/PCR DNA Fragments Extraction Kit.

\section{HASIL DAN PEMBAHASAN Kondisi Umum Lokasi Penelitian}

Perairan pantai Purnama Dumai termasuk wilayah Kelurahan Purnama Kecamatan Dumai Barat. Secara geografis Perairan Pantai Purnama Dumai berada pada titil kordinat $1^{\circ} 42^{\prime} 10^{\prime \prime}$ - $1^{\circ} 43^{\prime} 05^{\prime \prime}$ LU dan $101^{\circ} 22^{\prime} 45^{\prime \prime}$ - $101^{\circ} 24^{\prime} 10^{\prime \prime}$ BT. Tempat pengambilan sampel dan titik kordinat dapat dilihat pada Tabel 1.

Tabel 1. Titik Stasiun Lokasi Sampling

\begin{tabular}{cll}
\hline Stasiun & \multicolumn{1}{c}{ Tempat } & \multicolumn{1}{c}{ Titik Koordinat } \\
\hline Stasiun 1 & Hutan Mangrove Stasiun & $\mathrm{N}: 01^{\circ} 42^{\prime} 50,57^{\prime \prime}$ \\
& Kelautan Purnama & $\mathrm{E}: 101^{\circ} 23^{\prime} 19,17^{\prime \prime}$ \\
Stasiun 2 & Rumah Kapal & $\mathrm{N}: 01^{\circ} 42^{\prime} 54,39^{\prime \prime}$ \\
& & $\mathrm{E}: 101^{\circ} 23^{\prime} 15,31^{\prime \prime}$ \\
Stasiun 3 & Muara Sungai Mesjid & $\mathrm{N}: 01^{\circ} 43^{\prime} 11,03^{\prime \prime}$ \\
& & $\mathrm{E}: 101^{\circ} 23^{\prime} 14,05^{\prime}$ \\
\hline
\end{tabular}

\section{Isolasi Bakteri}

Pengambilan sampel dilakukan pada 3 stasiun dimana jumlah isolasinya sebanyak 81 isolat, dimana disetiap stasiun berjumlah 27 isolat. Berdasarkan hasil isolasi bakteri proteolitik yang ditumbuhkan pada medium Skim Milk Agar. Di dapatkan 10 isolat yaitu AZ1,
AZ2, AZ3, AZ4, AZ6, AZ10, AZ11, AZ15, AZ18, dan AZ20. Isolat bakteri ini memiliki bentuk morfologi koloni yang dapat dilihat dari diameter, bentuk koloni, waarna, tepian, permukaan, dan jumlah koloni. Lebih jelas dapat dilihat pada Tabel 2.

Tabel 2. Morfologi koloni isolat bakteri dari sedimen mangrove

\begin{tabular}{cccccccc}
\hline $\begin{array}{c}\text { Kode } \\
\text { Isolat }\end{array}$ & Stasiun & $\begin{array}{c}\text { Diameter } \\
(\mathbf{m m})\end{array}$ & $\begin{array}{c}\text { Bentuk } \\
\text { Kolonni }\end{array}$ & Warna & Tepian & Permukaan & $\begin{array}{c}\text { Jumlah } \\
\text { Koloni }\end{array}$ \\
\hline AZ1 & II & 10 & Bulat & Kuning Putih & Licin & Timbul & 32 \\
AZ2 & II & 6 & Rizoid & Kuning Merah & Licin & Timbul & 36 \\
AZ3 & III & 2 & Bulat & Putih & Licin & Timbul & 39 \\
AZ4 & I & 3 & Bulat & Kuning Putih & Licin & Timbul & 75 \\
AZ6 & II & 2 & Bulat & Kuning Putih & Licin & Timbul & 31 \\
AZ10 & III & 2 & Bulat & Kuning Putih & Licin & Timbul & 35 \\
AZ11 & III & 2 & Rizoid & Kuning Putih & Licin & Timbul & 37 \\
AZ15 & I & 3 & Rizoid & Kuning Putih & Licin & Timbul & 38 \\
AZ18 & I & 6 & Bulat & Kuning Putih & Licin & Timbul & 39 \\
AZ20 & III & 1 & Bulat & Kuning Putih & Licin & Timbul & 30 \\
\hline
\end{tabular}


Bentuk bakteri dapat dibagi kedalam tiga golongan yaitu kokus, basil dan bentuknya lain yang bervariasi. Bakteri kokus memiliki bentuk bulat seperti bola namun pada perkembangannya bakteri ini bentuknya bisa bervariasi. Bakteri basil memiliki bentuk batang atau silinder namun bisa juga memiliki beberapa variasi bentuk lainnya (Hidayat, 2011). Berdasarkan penelitian yang didapatkan untuk morfologi koloni bakteri dari bentuk adalah bulat.

\section{Uji Biokimia}

Uji biokimia merupakan salah satu uji yang digunakan untuk menentukan spesies bakteri secara manual, karena setiap bakteri memiliki sifat biokimia yang berbeda sehingga tahapan uji biokimia ini sangat membantu proses identifikasi. Bakteri diidentifikasi. dengan mengamati reaksi biokimia dari bakteri tersebut terhadap beberapa medium uji. Uji biokimia yang dilakukan pada penelitian ini di antaranya yaitu uji pewarnaan Gram, motilitas, indol, katalase, sitrat, sulfida, dan TSIA. Berdasarkan hasil pengujian morfologi untuk uji pewarnaan Gram yaitu terdapat besifat Gram positif (+) yang ditandai dengan sel berwarna ungu. Bakteri jenis ini akan berwarna biru atau ungu dibawah mikroskop, sedangkan bakteri gram negatif akan berwarna merah. Hasil dari uji biokimia setiap isolat bakteri dapat dilihat Tabel 3.

Tabel 3. Karakteristik Biokimia Isolat Bakteri

\begin{tabular}{|c|c|c|c|c|c|c|c|c|}
\hline \multirow{3}{*}{ Kode Isolat } & \multicolumn{8}{|c|}{ Uji Biokimia } \\
\hline & \multirow{2}{*}{$\begin{array}{l}\text { Pewarnaan } \\
\text { Gram }\end{array}$} & \multirow[t]{2}{*}{ Motilitasi } & \multirow[t]{2}{*}{ Indol } & \multirow[t]{2}{*}{ Katalase } & \multirow[t]{2}{*}{ Sitrat } & \multirow[t]{2}{*}{ Sulfida } & \multicolumn{2}{|c|}{ TSIA } \\
\hline & & & & & & & $\mathbf{T}$ & M1 \\
\hline AZ1 & $+($ Bacil $)$ & - & - & + & - & - & $\mathrm{K}$ & $\mathrm{K}$ \\
\hline AZ2 & $+($ Coccus $)$ & + & - & + & - & - & $\mathrm{K}$ & $\mathrm{K}$ \\
\hline AZ3 & $+($ Coccus $)$ & + & - & + & - & - & $\mathrm{K}$ & $\mathrm{K}$ \\
\hline AZ4 & $+($ Bacil $)$ & + & - & + & - & - & $\mathrm{K}$ & $\mathrm{K}$ \\
\hline AZ6 & $+($ Coccus $)$ & + & - & + & - & - & $\mathrm{K}$ & $\mathrm{K}$ \\
\hline AZ10 & $+($ Bacil $)$ & + & - & + & + & - & $\mathrm{K}$ & $\mathrm{K}$ \\
\hline AZ11 & + (Bacil) & - & - & + & + & - & $\mathrm{K}$ & $\mathrm{K}$ \\
\hline AZ15 & $+($ Bacil $)$ & + & - & + & - & - & $\mathrm{K}$ & $\mathrm{K}$ \\
\hline AZ18 & $+($ Bacil $)$ & + & - & + & - & + & M & M \\
\hline AZ20 & $+($ Bacil $)$ & + & - & + & + & - & $\mathrm{K}$ & $\mathrm{K}$ \\
\hline
\end{tabular}

Keterangan : (+) : Uji bersifat positif, (-) : Uji bersifat negatif, $\mathrm{T}$ : Posisi tegak, M1: Posisi agak miring, $\mathrm{K}$ : Berwarna kuning, $\mathrm{M} \quad$ : Berwarna merah

Menurut Sari (2017) Bakteri gram positif mampu mengikat sangat kuat dan pori-pori tidak mudah membesar karena lapisan bakteri tidak banyak mengandung lipid sehingga pada saat pencucian dengan alkohol kristal violet tidak larut, sedangkan gram negatif menghasilkan warna kemerahan atau merah muda karena saat pewarnaan pori-pori lapisan bakteri tersebut membesar karena lapisan tersebut mengandung lipid. Dwijoseputro (2017) mengatakan bahwa bentuk tubuh (sel) bakteri dipengaruhi oleh keadaan medium dan usia bakteri.
Untuk uji motilitas semua isolat bersifat positif $(+)$, sedangkan isolat AZ1 dan AZ18 uji motil bersifat negatif (-). Menurut Sudarsono (2008) uji motilitas bersifat positif ditandai dengan pertumbuhan bakteri yang menyebar, maka bakteri tersebut bergerak (motil) dan bila pertumbuhan bakteri tidak menyebar hanya berupa satu garis maka bakteri tersebut tidak bergerak. Berdasarkan (Semuel et al., 2013) uji motilitas ditandai dengan pertumbuhan koloni pada media SIM jika bersifat postif dan jika bersifat negatif ditandai dengan tidak adanya pertumbuhan 
koloni yang terdapat pada media tumbuh SIM.

Untuk uji indol pada semua isolat bakteri bersifat negatif (-) yang ditandai larutnya senyawa amino benzealdehid dalam air sehingga tidak membentuk warna merah seperti cincin sebagai pembentukan indol. Uji indol dilakukan untuk mengetahui kemampuan bakteri memecah triptofan asam amino membentuk senyawa indol. Triptofan dihidrolisis oleh triptofanase untuk menghasilkan tiga kemungkinan produk akhir, salah satunya adalah indol. Produksi indol terdeteksi oleh reagen Kovac atau Ehrlich yang tersusun atas 4-p-benzaldehid dimethylamino, reagen ini bereaksi dengan indol, sehingga menghasilkan senyawa berwarna merah. Reaksi positif ditandai jika terdapat warna merah pada permukaan medium yang menunjukkan bahwa bakteri mampu memecah asam amino triptofan (Acharya, 2012).

Untuk hasil uji katalase pada semua isolat bakteri bersifat positif (+) yang ditandai dengan pembentukan gelembung udara pada media Nutrien Broth sebagai tanda bakteri dapat membentuk $\mathrm{O}_{2}$ dengan memproduksi enzim katalase lewat degradasi hidrogen peroksida yang dilakukan oleh bakteri. Menurut Wahid (2009) pada bakteri yang bersifat katalase positif akan terlihat adanya gelembung gas dan jika gelembung gas tidak terbentuk berarti katalase bersifat negatif. Bakteri katalase negatif tidak memiliki enzim katalase yang menguraikan $\mathrm{H}_{2} \mathrm{O}_{2}$ (Cappucino dan Sherman, 2017).

Mekanisme enzim katalase memecah $\mathrm{H} 2 \mathrm{O} 2$ yaitu saat melakukan respirasi, bakteri menghasilkan berbagai macam komponen salah satunya $\mathrm{H} 2 \mathrm{O} 2$. Bakteri yang memiliki kemampuan memecah $\mathrm{H} 2 \mathrm{O} 2$ dengan enzim katalase maka segera membentuk suatu system pertahanan dari toksik $\mathrm{H} 2 \mathrm{O} 2$ yang dihasilkannya sendiri (Murali, 2017).
Untuk hasil uji sitrat pada isolat AZ10, AZ11, dan AZ20 bersifat positif (+) yang ditandai dengan perubahan warna pada medium Simmons's Citrate Agardari warna hijau menjadi warna biru karena terjadi peningkatan $\mathrm{pH}$ pada media karena adanya ammonia yang dihasilkan monoamomonia fosfat yang terdapat pada media (Sardiani et al, 2015).

Untuk hasil uji Sulfida $\left(\mathrm{H}^{2} \mathrm{~S}\right)$ pada isolat AZ1, AZ2, AZ3, AZ4, AZ6, AZ10,AZ11,AZ15, dan AZ20, bersifat negatif (-) yang ditandai dengan tidak terbentuk endapan berwarna hitam pada dasar media Triple Sugar Iron Agar sebagai tanda bakteri dapat menghasilkan $\mathrm{H}^{2} \mathrm{~S}$, Sedangkan AZ18 bersifat positif (+). Menurut Suhandono dalam adithya (2017) menyatakan bahwa uji sulfida mudah untuk dideteksi karena bau gas $\mathrm{H}^{2} \mathrm{~S}$ yang seperti telur busuk atau terjadinya penghitaman dari proses inokulasi.

Hasil uji pada media Triple Sugar Iron Agar (TSIA) isolat bakteri AZ1,AZ2, AZ3, AZ4, AZ6, AZ10, AZ11, AZ15, dan AZ20 berwarna kuning pada media tegak dan miring sebagai tanda isolat tersebut mampu memfermentasikan glukosa, laktosa, dan sukrosa.

Menurut Silitonga et al. (2016) bahwa isolat bakteri hetorotrofik yang memfermentasi glukosa, laktosa, dan sukrosa ditandai dengan berubah warna media agar tegak berwarna kuning dan media agar miring berwarna merah. Sedangkan isolat bakteri yang memfermentasi glukosa, laktosa dan sukrosa, hal ini ditandai dengan berubahnya warna merah dan media miring berwarna kuning bakteri tersebut mampu memfermentasi glukosa. Jika media tegak dan miring berwarna merah bakteri tidak mampu memfermentasi glukosa, laktosa, dan sukrosa.

\section{Uji Antagonisme terhadap Baktreri}

Hasil pengamatan uji antagonisme dari 10 isolat bakteri terhadap 3 bakteri 
patogen yaitu Bakteri Pseudomonas aerugunosa, Escherichia coli, dan Vibrio alginolyticus menunjukan tidak semua mampu menghambat pertumbuhan bakteri patogen. Lebih jelas dapat dilihat pada Gambar 1.

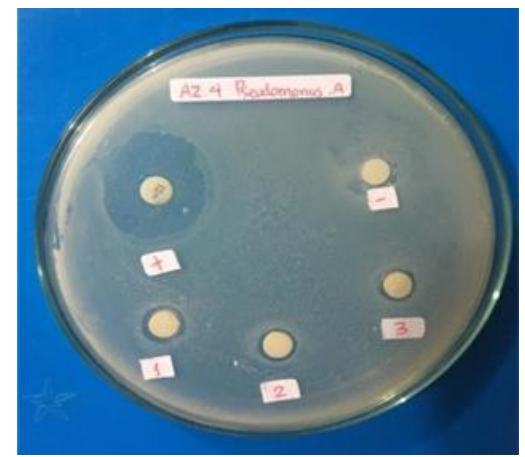

Keterangan:

$(+)$ : control positif,

(-) : control negative $(1,2,3)$

Ulangan

Gambar 1. Daya hambat isolat bakteri proteolitik terhadap bakteri patogen
Menurut Greenwood dalam Afriza et al (2019) bahwa terdapat beberapa klasifikasi respon hambatan pertumbuhan bakteri. Jika diameter zona hambat lebih besar dari $20 \mathrm{~mm}$ maka respon hambatan pertumbuhannya sangat kuat, sedangkan diameter zona hambat berkisar antara 10$20 \mathrm{~mm}$ maka respon hambatan pertumbuhannya dikategorikan kuat. Apabila diameter zona hambat berkisar antara 5-10 $\mathrm{mm}$ maka respon hambatan pertumbuhannya dikategorikan sedang, sementara diameter zona hambat lebih kecil dari $5 \mathrm{~mm}$ maka respon hambatan pertumbuhannya dikategorikan lemah. Aktifitas dari 10 isolat ditunjukan dengan adanya zona bening pada sekitar cakram, kemudian diukur zona bening yang terbentuk. Lebih jelas dapat dilihat pada Tabel 4

Tabel 4. Antagonisme Isolat Bakteri Proteolitik terhadap Bakteri Patogen

\begin{tabular}{cccc}
\hline \multirow{2}{*}{ Kode Isolat } & \multicolumn{3}{c}{ Zona Hambat $(\mathbf{m m}) \mathbf{\pm S t d . D e v}$} \\
\cline { 2 - 4 } & $\boldsymbol{P .}$ aeruginosa & $\boldsymbol{E}$. coli & V.alginolyticus \\
\hline AZ1 & $2,25 \pm 0,95$ & $4,21 \pm 0,64$ & $1,41 \pm 0,84$ \\
AZ2 & $9,65 \pm 1,55$ & $2,88 \pm 0,95$ & $1,05 \pm 0,69$ \\
AZ3 & $2,11 \pm 0,64$ & $4,41 \pm 0,51$ & $2,71 \pm 2,16$ \\
AZ4 & $2,58 \pm 0,15$ & $2,68 \pm 1,00$ & $2,41 \pm 0,42$ \\
AZ6 & $8,05 \pm 1,41$ & $5,18 \pm 2,18$ & $2,48 \pm 1,19$ \\
AZ10 & $2,55 \pm 0,69$ & $2,51 \pm 1,40$ & $1,31 \pm 0,92$ \\
AZ11 & $2,11 \pm 0,49$ & $3,21 \pm 2,05$ & $3,61 \pm 0,58$ \\
AZ15 & $3,55 \pm 2,12$ & $1,81 \pm 1,03$ & $2,25 \pm 0,52$ \\
AZ18 & $2,10 \pm 0,61$ & $1,75 \pm 1,21$ & $2,38 \pm 0,55$ \\
AZ20 & $3,05 \pm 2,71$ & $5,15 \pm 0,62$ & $4,01 \pm 1,37$ \\
\hline
\end{tabular}

\section{Hasil Elektroforesis DNA}

Elektroforesis DNA total dengan $1 \%$ gel agarose, tegangan 50 Volt selama 45 menit, menunjukan DNA kromosomal yang

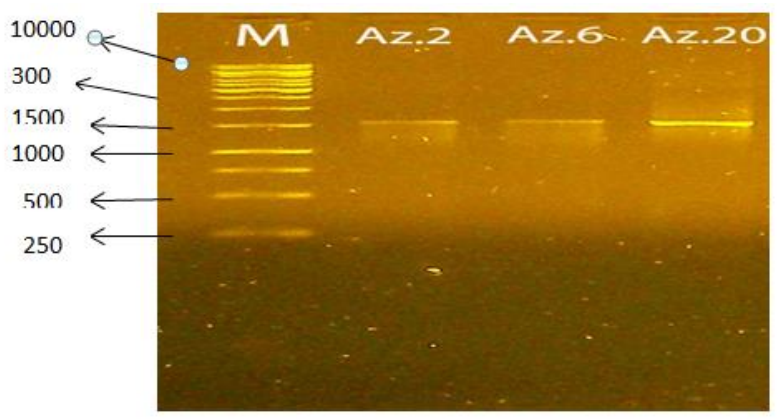

telah dimurnikan dapat dilihat pada Gambar 2.
Keterangan :

M : Fragmen marker DNA

Az.2 : Isolat bakteri

Az.6 : Isolat bakteri

Az.20 : Isolat bakteri

Gambar 2. Hasil Elektroforesis isolat bakteri proteolitik 


\section{Analisis BLAST (Basic Local Alignment Search Tool)}

Analisis BLASST dari fasta DNA didapatkan hasil sequencing dengan merujuk pada Genkbank menunjukan bahwa AZ2 memiliki tingkat kekerabatan dengan bakteri Bacillus proteolyticus dengan nilai homolog yaitu 99,26\% dan strain MCCC 1A00365. Pada AZ6 memiliki tingkat kekerabatan dengan bakteri $B$. manliponensis dengan nilai homolog yaitu 98,09\% dan strain BL4-6. Sementara pada AZ20 memiliki tingkat kekerabatan dengan bakteri B. toyonensius dengan nilai homolog yaitu $99,67 \%$ dan strain BCT-7112. Menurut Feliatra et al. (2015) menyatakan bahwa isolat yang mempunyai persamaan homolog antara lebih dari $97 \%$ dapat mewakili pada tingkat spesies yang sama. Lebih Jelas dapat dilihat pada Tabel 5.

Tabel 5. Hasil BLAST isolat bakteri proteolitik

\begin{tabular}{llllll}
\hline Kode Isolat & \multicolumn{1}{c}{ Spesies } & Strain & Kode akses & Referensi & Homolog \\
\hline AZ2 & $\begin{array}{l}\text { Bacillus } \\
\text { proteolyticus }\end{array}$ & $\begin{array}{l}\text { MCCC } \\
\text { 1A00365 }\end{array}$ & NR_157735.1 & $\begin{array}{c}\text { Liu,Y.,et al. } \\
(2014)\end{array}$ & $99,26 \%$ \\
AZ6 & $\begin{array}{l}\text { Bacillus } \\
\text { manliponensis }\end{array}$ & BL4-6 & NR_125530.1 & $\begin{array}{c}\text { Jung,M.Y. and } \\
\text { Chang,Y.H. } \\
(2014)\end{array}$ & $98.09 \%$ \\
AZ20 & Bacillus toyonensis & BCT-7112 & NR_121761.1 & $\begin{array}{c}\text { Jimenez,G., } \\
\text { Blanch } \text { et al., } \\
(2013)\end{array}$ & $99.67 \%$ \\
\hline
\end{tabular}

Selain dapat dilihat pada Tabel 5. data ditampilkan dalam bentuk pohon filogenetik menggunakan aplikasi program
UPGMA. Seperti pada Gambar 3 dibawah ini:

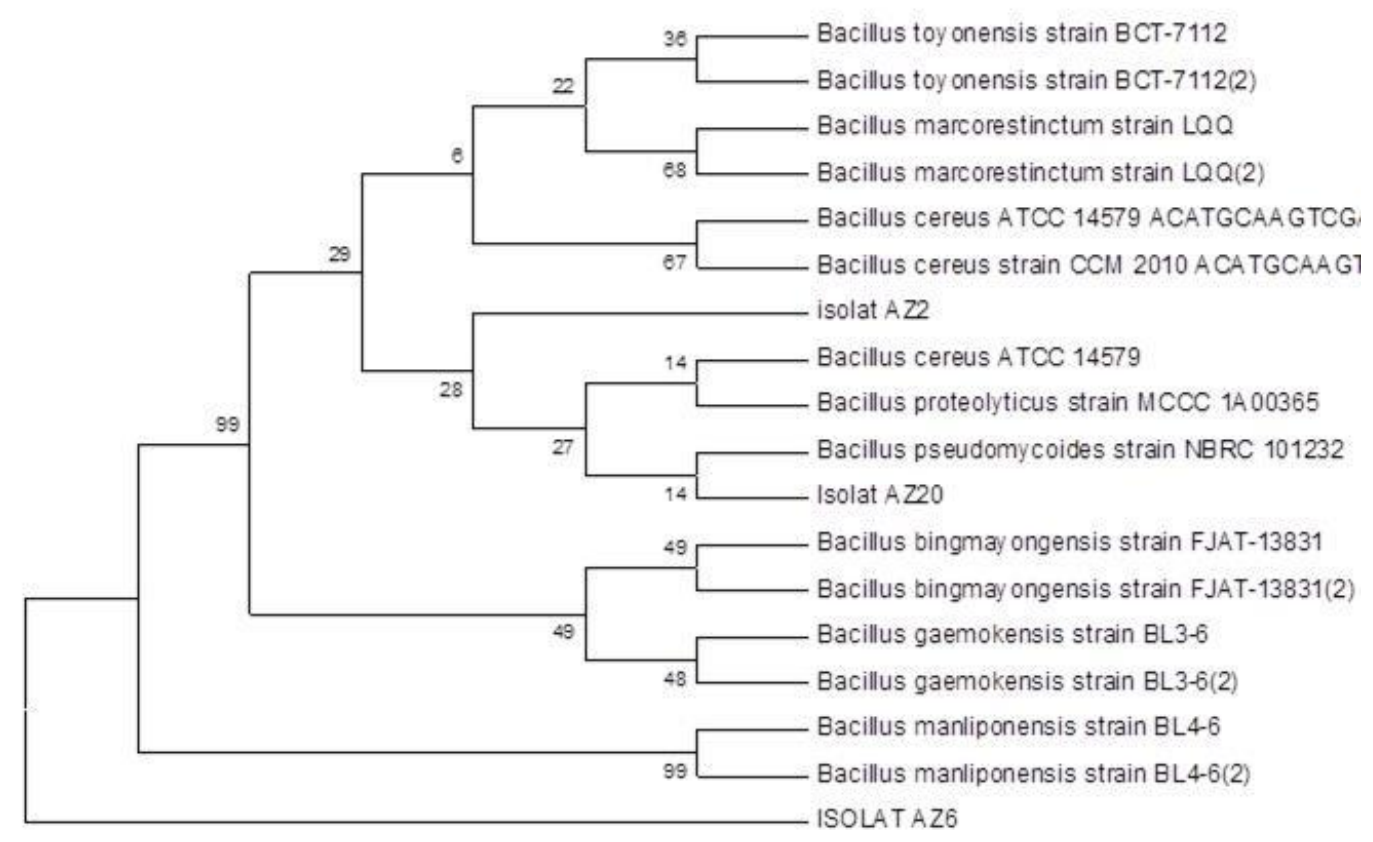

Gambar 3. Pohon Filogenetik 


\section{KESIMPULAN DAN SARAN}

\section{Kesimpulan}

Pada penelitian ini didapatkan 10 isolat bakteri yang memiliki aktifitas antagonisme terhadap bakteri patogen antara lain bakteri P. aerugunosa, E. coli, dan $V$. alginolyticus, yang didapati hasil pada isolat bakteri Pseudomonas aerugunosa berkisar antara 2,01-9,65 mm, diameter zona hambat isolat bakteri yang tertinggi yaitu isolat $\mathrm{AZ2}$ dan terendah yaitu AZ18. Bakteri terhadap bakteri Escherichia coli berkisar antara 1,75-5.18 $\mathrm{mm}$, diameter zona hambat bakteri yang tertinggi yaitu isolat AZ6 dan yang terendah yaitu isolat AZ18. Sedangkan bakteri Vibrio algynoliticus berkisar antara 1,05-4,01 mm, diameter zona hambat bakteri yang tertinggi yaitu isolat AZ20 dan yang terendah yaitu isolat AZ2.
Hasil identifikasi dengan menggunakan analisis 16S rRNA diketahui bahwa 3 isolat menunjukan hasil yang berbeda. AZ2 memiliki kekerabatan pada bakteri $B$. proteolyticus, AZ6 memiliki kekerabatan pada bakteri $B$. monlinensis, dan AZ20 memiliki kekerabatan pada bakteri $B$. toyonensis. Berdasarkan pada penelitian ini didapatkan 10 isolat bakteri berdasarkan morfologi koloni bakteri yang pada kesemuanya tidak memiliki perbedaan yang mencolok baik dalam bentuk, warna, tepian, maupun jumlah koloni bakteri.

\section{Saran}

Disarankan untuk penelitian selanjutnya agar meneliti pengaruh bakteri proteolitik sebagai produk pakan pada makhlup hidup.

\section{DAFTAR PUSTAKA}

1. Acharya, T. (2012). Indole Test: Principle, Procedure and Results (Online). http: //microbeonline.com /indole-test-principle-procedure-results/. Di akses tanggal 15 Agustus 2019.

2. Afriza, D., I. Effendi, YI. Siregar. (2019). Isolation, Identification andAntagonisme Test of Heterotrophic Bacteria in Mangrove Plants Againts Pathogenic bacteria (Vibrio alginolyticus, Aeromonas hydrophila, and Pseudomonas sp. Jurnal Perikanan dan Kelautan, Volume 24(1). Pages 61-68

3. Akhdiya, A. (2017). Isolasi bakteri penghasil enzim protease alkalin termostabil. Buletin Plasma Nutfah. Volume 9(2), pages 38-44.

4. Cappucino, JG and N. Sherman. (2017). Microbiology : A Laboratory Manual. Edisi Kedua. New York : Benjamin Cummings Publishing Company.

5. Dwidjoseputro, D. 2017. Dasar-Dasar Mikrobiologi. Djambatan. Jakarta. $214 \mathrm{hlm}$

6. Hidayat, H. (2011). Karakterisasi Molekuler BAL Dengan Gen 16S rRNA Penghasil ENzim Protease Yang berpotensi sebagai Probiotik Dari Fermentasi Markisa Kuning di Sumatera Barat.Padang: Universitas Andalas.

7. Murali, A and S. Patel. (2017). The Effect of Different Heavy Metal Acetate Solutions on the Inhibition of Catalase Enzyme. Journal of the South Carolina Academy of Science, Volume 15(2), pages 13.

8. Nora, I., K. Adelita, MSJ. Sofiana. (2019). Penapisan aktivitas Amilolitik dan Antibakteri dari Bakteri Sedimen Perairan Pulau Lemukutun. Jurnal Enggano. Volume.4 (1) : pages 65-71.

9. Sardiani. N, M. Litaay, RG. Budji, D. Priosambodo, Syahribulan, dan Z. Dwyana. (2015). Potensi Tunikata Rhopalaea sp sebagai Sumber Inokulum Bakteri Endosimbion Penghasil Antibakteri, Karakterisasi Isolat. Jurnal Alam dan Lingkungan. Volume 6 (11). 
10. Sari., YN. Maya, S. Sumyarti dan Jamsari. (2013). Isoalsi, Karakterisasi dan Identifikasi DNA Bakteri Asam Laktat (BAL) yang Berpotensi sebagai Antimikroba dan Fermentasi Markisa Kuning (Passiflora edulisvar flavicarfa). Jurnal Kimia Unand. Volume 2(2).

11. Sayuti, I., N. Istami, dan H. Butar-Butar. 2016. Isolasi dan identifikasi bakteri limbah minyak bumi dari perairan pelabuhan sungai duku. Program Studi Pendidikan Biologi Fakultas Keguruan dan Ilmu Pendidikan Universitas Riau.

12. Semuel, F., Lumantouw, EF. Febby, BR. Sendy, FO. Marina, dan Singkoh. (2013). Isolasi dan Identifikasi Bakteri yang Toleran terhadap Fungisida Mankozeb pada Lahan PertanianTomatdi Desa Tempok, Kecamatan Tompaso, Sulawesi Utara. Jurusan Biologi Fakultas MIPA Universitas Sam Ratulangi Manado

13. Silitonga, LR., Nursyirwani, dan I. Effendi. (2019). Isolation, Identification, and Sensitivity of Amilolitic Bacteria from Mangrove Ecosystem Sediment in Purnama Marine Station Dumai on the Pathogenic Bacteria. Asian Journal of Aquatic Sciences, Volume 2(3). Pages 257-266

14. Sudarsono, A. (2008). Isolasi dan Karakterisasi Bakteri pada Ikan Laut dalam Spesies Ikan Gindara (Lepidocibium flavobronneum).Skripsi]. Bogor: Institut Pertanian Bogor.

15. Wahid, I., Mubarak, dan N. Chayatin. (2009). Ilmu Kesehatan Masyarakat Teori dan Aplikasi. Salemba Medika, Jakarta. 